\title{
Features of taxation in agriculture in the Russian Federation and abroad: comparative analysis.
}

\author{
Liana Barashyan ${ }^{1, *}$ \\ ${ }^{1}$ Institute of Service Sector and Entrepreneurship (Branch) of the Don State Technical University in \\ Shakhty, Shevchenko 147, the city of Shakhty, 346500 Rostov Region, Russia
}

\begin{abstract}
The article was completed on the topic "Features of taxation in agriculture in the Russian Federation and abroad: comparative analysis." In the article, the author discloses the features of taxation in agriculture in Russia and in a number of European states. Conducts an analysis of the effectiveness of the current system and offers directions for its improvement. The experience of agricultural taxation in developing countries is examined, conceptual and practical problems related to different tax regimes are analyzed. The main problem in the study countries is the measurement of (actual) agricultural income. Various measures of estimated income were used with varying success. In this article, the issues of legal regulation of agricultural taxation in Russia and abroad, the right to use nature in agricultural activities were investigated, the problems of regulatory support for rational environmental use in agriculture were identified, and the directions for optimizing the legislative regulation of the use of natural resources for agricultural activities were determined.
\end{abstract}

\section{Introduction}

One of the defining features of the state is its ability to increase revenues. Whether a State is strong or weak, resolute or inferior, will survive or disintegrate ultimately depends on its balance. Thus, public finance is more than a purely economic phenomenon. [1]

From the point of view of agricultural activities, the role of the state is very important, whether it is the regulation of economic relations or the creation of an institutional framework for the conduct of stakeholders in these activities. As a regulator of various social processes, the state plays an important role in the field of taxation, thereby establishing a market balance between agricultural producers. In an attempt to regulate its tax system most simply and comprehensively, without impeding market space, the state must at the same time achieve tax, political, economic, social and other goals by taxing agriculture. The scale of the tax burden of agriculture as an economic activity is important for achieving a sustainable level of development of this industry. Therefore, agricultural taxation must be approached with full respect for the goals and economic interests of the parties concerned. [2]

This requires the active role of economic and political authorities, which are reflected in the application of the necessary regulations in the process of establishing a balance in the

\footnotetext{
* Corresponding author: barashyan.liana@yandex.ru
} 
agricultural market. Within the framework of the economic policy of taxation, the state plays the role of a regulator in the distribution of national income, a distributor of funds, a stabilizer of market fluctuations and a catalyst for economic growth. [3]

The formation of adequate conditions in the model of the market economy of Russia requires the creation of a solid financial base. An important place in the mobilization of financial resources of society is played by the tax system, with its characteristic characteristics of each state and the specificity of the tasks performed at a certain stage. [4] The formation and development of a market economy based on private property, accompanied by the expansion of business, the agro-industrial complex and the creation of small enterprises, the activation of various financial and credit institutions, which will lead to an increase in the number of real taxpayers. In this regard, relations between the state in the person of tax structures and small businesses as taxpayers are aggravated. The financial and legal responsibility of taxpayers is strengthened, which consists in the application of financial sanctions to offenders, which are measures of financial and legal coercion. [5]

The existing tax system in Russia provides an individual approach to the taxation of entrepreneurship, depending on the types of activities, special tax regimes can be applied, which are developed by the state to regulate individual business sectors, as well as to simplify tax payments. Special tax regimes are described in section VIII.I "Special tax regimes." [6]

The current reality, the current economic situation in the world poses special requirements for ensuring the food security of the state and conducting import substitution. The purpose of the study is to identify the advantages and disadvantages of the agricultural taxation system in the form of a single agricultural tax, the impact of changes made to the Tax Code. According to the results of the study, it was concluded that the application of a single agricultural tax in practice raises questions that need to be reviewed and clarified, especially with regard to the effectiveness of the special regime used in the development of small businesses in the agricultural sector. It is proposed to abolish the exemption from value added taxes of all payers of a single agricultural tax, regardless of their income, and use the indicator. [7]

\section{Methodology}

The methodological basis is a systematic approach, which focuses the study on the study of the agricultural taxation system as a holistic complex, which allows us to determine not only the basis of regulatory regulation, but also its effectiveness. The study also used general scientific methods - dialectical, formal logic, analysis and synthesis; private scientific methods - logical-legal, comparative-legal, document analysis, analysis of print and electronic publications, statistical methods. Consideration of the problems of regulatory regulation of agricultural taxation caused the need to involve methods of a structural and functional approach.

\section{Results of the research}

One of the features of the tax regulation of the agro-industrial complex (hereinafter referred to as agro-industrial complex) was that after the introduction of new rules established by the Tax Code, enterprises managed to adapt to the new requirements of tax legislation, their leaders began the process of actively using its main disadvantage - the inability to take into account the peculiarities of the agrarian business. More and more land is concentrated in agricultural holdings. Their accelerated development is almost the main factor in the formation of significant imbalances in the development of agribusiness in our country. Overproduction in some industries occurs in parallel with underproduction in others. It is 
obvious that tax innovations introduced by the Tax Code will not overcome the causes of these imbalances in the sectoral structure of production, since they do not change the taxation system of agricultural enterprises. [8] The introduction of a single agricultural tax is largely connected with the desire to support owners of small and medium-sized businesses by reducing the tax burden and simplifying the procedure for calculating and paying tax. In addition, the intensification and growth of entrepreneurial activity in the agricultural sector contribute to improving the standard and quality of life of the rural population. [7]

The study identified deficiencies in the single agricultural tax, such as:

- low interest of taxpayers in its application;

- The need for constant monitoring of income from the sale of agricultural products so that it does not exceed 70 per cent of total income;

- Unlike the general tax regime, in which the list of expenses is open, while under a single agricultural tax - closed;

- loss of part of the market in the conditions of interest of large processing enterprises and retail chains in VAT (before making corresponding changes);

- The special tax regime in the form of a single agricultural tax is not sufficiently flexible and therefore it is not possible to regulate certain processes in the productive sector; the main goal of introducing a single agricultural tax is to increase the investment attractiveness of agricultural production.

In our opinion, the advantages of a single agricultural tax are:

- Minimizing taxes by paying a single tax in lieu of corporate income tax, corporate property tax;

- No restrictions on the return to the general tax regime;

- a low single tax rate with a single agricultural tax (6\%) compared to the general regime $20 \%$, with a simplified tax system $-15 \%$;

- The frequency of filing a declaration is only once a year.

In 2018, compared to 2016, the turnover of small enterprises (including microenterprises) increased by $37.1 \%$, including in agriculture - by $44.5 \%$. Investments in the fixed capital of small enterprises (including microenterprises) increased by $21.0 \%$ during the period, including in agriculture - by $34.8 \%$. Investments in fixed assets by 1 ruble of turnover decreased by $11.7 \%$, including in agriculture - by $6.7 \%$. At the same time, funds were invested in small enterprises engaged in agriculture in 2016 by 8 times more, in 2018 - by 8.5 times more than in general for all small enterprises. Next, we will consider calculating the tax base and tax liabilities for a single agricultural tax.

Table 1. Indicators of application of special tax regimes in $2017-2018$

\begin{tabular}{|c|c|c|c|}
\hline $\begin{array}{c}\text { Special tax regime } \\
\text { Indicator }\end{array}$ & $\mathbf{2 0 1 7}$ & $\mathbf{2 0 1 8}$ & $\begin{array}{c}\text { Growth rate, } \\
\text { \% }\end{array}$ \\
\hline $\begin{array}{c}\text { Simplified tax system } \\
\text { Income, billion rubles }\end{array}$ & 13130 & 16967 & 129.2 \\
\hline $\begin{array}{c}\text { Unified imputed income } \\
\text { tax } \\
\text { Income, billion rubles }\end{array}$ & 892 & 904 & 101.3 \\
\hline $\begin{array}{c}\text { Unified agricultural tax } \\
\text { Income, billion rubles }\end{array}$ & 1549 & 1690 & 109.1 \\
\hline
\end{tabular}

As practice shows, the exclusion of special regimes, including taxpayers of single agricultural products, from VAT does not contribute to the development of small businesses: the inability to include the amount of "input" VAT in the cost of goods (works, services) sold is limited by many organizations working with organizations that pay VAT, since the latter are most interested in deducting the amount of VAT, which in practice led to the refusal to 
work with VAT defaulting entities (special regimes, as well as with persons receiving VAT exemption under Article 145 of the Tax Code of the Russian Federation).

The shift from a single agricultural tax to VAT for many entrepreneurs to the agricultural sector means that the tax system has ceased to be convenient and comfortable, facilitating the difficult life of a person doing business in agriculture. From 2019, such a system can remain convenient only if the application for release or income is submitted in a timely manner in accordance with the established limit. [9]

The existence of such a special tax regime is largely due to the desire to support small and medium-sized business owners by reducing the tax burden and simplifying the tax collection procedure.

Since agribusiness is labor-intensive and has unstable profitability, special tax procedures become priority factors for improving the financial condition of business owners. Moreover, the intensification and growth of entrepreneurial activity in the agricultural sector contributes to the improvement of the standard and quality of life of the rural population. In this regard, an increase in the number of taxpayers applying special tax regimes in recent years is logical. [10]

\section{Discussion of results}

Income from the agricultural sector averages Euro12,600 per EU (economy average Euro25,000). The actual income of Denmark - 52,700 euros from agriculture is profitably different from the income of 5,000 euros in Slovenia, Poland, Bulgaria, Latvia, Romania and Croatia. The low factor income of many Member States indicates that exempt farmers should not be burdened with VAT inputs and that the cost of enforcement for taxable farmers should be minimized. [11]

Modern fiscal policy in the field of agriculture is not objective due to the use of only stimulating instruments of the tax mechanism. Its implementation over time led to a violation of the structure of agricultural production and the competitive environment, a differentiation of the level of tax burden on producers of various forms of business and specialization of production, and a lack of sources of replenishment of local budgets. [12]

In the modern period, it is relevant to assess the strengthening of special regimes with direct taxation of agro-industrial complex producers. This article presents a comparative analysis of special direct tax regimes, their peculiarities in agriculture, an assessment of the effectiveness of special tax regimes by determining their share in the formation of budgets, determining the actual potential for the size of tax bases, and coordinating the level of tax burden on taxpayers according to individual tax forms. To determine modern trends in the development of the agricultural sector in the formation of the tax mechanism, it is proposed to expand the structure and establish sufficient criteria for the possibility of payers applying special direct tax regimes. [13]

Modern fiscal policy in the field of agriculture is not objective due to the use of only stimulating instruments of the tax mechanism. Its implementation over time led to a violation of the structure of agricultural production and the competitive environment, a differentiation of the level of tax burden on producers of various forms of business and specialization of production, and a lack of sources of replenishment of local budgets.

The recent crisis in the agricultural sector has highlighted the need to assist business operators through actions that increase system efficiency and reduce costs, including through tax, financial and administrative concessions. Especially in more specialized areas, the experience of industrial areas, business networks and supply chains for which national legislation provides tax, administrative, financial and support benefits for research and development can be representative in this regard. In particular, it is essential to identify, in the light of the ongoing federal reform, good practices that define a model area as a form of 
territorial organization of local development, for example, to maximize economic and fiscal benefits. [14]

Taxation can and should be seen not only as the dominant source of the formation of centralized financial resources of the state, but also as one of the tools of state regulation of the economy to stimulate and support the activities of individual industries.

Features of taxation in agriculture include: tax incentives to attract investment; the need for environmental taxation; preferential tax and payment procedure; special procedure for land taxation; the use of a single tax.

\section{Conclusions}

The Russian system of agrarian taxation is characterized by frequent changes. Over the past twenty years, it has undergone a transformation from a unified approach for all industries to the creation of special conditions for agriculture, and, ultimately, the introduction of a special tax regime.

In order to stimulate the development of agricultural production and increase its economic efficiency, it is necessary to improve the tax mechanism taking into account the specific characteristics of individual industries. The special tax regime, as one of the organizational forms of tax regulation, should be designed in such a way that the tax mechanism, on the one hand, provides tax revenues to the budget, and on the other hand, stimulates the type of activity that the state decided to transfer to special tax conditions. [15]

The indifference and neglect of legislators to formalize the agricultural taxation regime clearly causes serious structural shortcomings in the fiscal mechanism. Addressing this problem, the study analysed the impact of taxes on agriculture, on the share of agriculture in GDP, and empirically investigated the long-term relationship between variables using time series data over the past 10 years. It was empirically found that higher taxes on agriculture led to a decrease in the share of agriculture in GDP. At the same time, the increase in land tax revenues had a significant positive impact on the share of agriculture in GDP. Exemption from agricultural income tax would give a respite to the agricultural community, as was done in China where a zero agricultural income tax was applied in practice. However, if income tax is to be implemented, these tax rates should be revised according to potential income from agricultural land; large land holdings are subject to taxation, part of the collected tax at the district level should be spent on the provision of local services, which, in turn, will help farmers increase income, which will lead to increased tax revenues. [16]

Agriculture has always been the focus of the Government, particularly because of its relationship with other sectors, its importance in foreign trade and its role in providing food in rural and urban areas. Indeed, agriculture accounts for 15 to 20 per cent of GDP and employs 44 per cent of the labour force. If you add the food industry, then its contribution to GDP and employment will be $15 \%$ and $50 \%$, respectively. However, agriculture suffers from low productivity, low yields, high logistics and production costs. For these reasons, agriculture enjoys tax incentives to encourage and encourage private and foreign investment. However, tax benefits have become a source of distortion and inefficient allocation of investment and resources in the sector. [17]

\section{References}

1. T. Baskaran, Taxation and Democratization. World Development, 56, 287-301 (2014) 
2. G. Milosevicr, M. Kulicr, Z. Duricr, O. Duricr, The Taxation of Agriculture in the Republic of Serbia as a Factor of Development of Organic Agriculture, Sustainability, 12, 3261, 14 - 17 (2020)

3. S. Vuksa, D. Andelicr, I. Kolarski, Uloga Ekonomske Politike u Ekonomskim Krizama. Oditor, 12, 13-21 (2015)

4. I.N. Dolgih, A.B. Zhdanova, K.A. Bannova, The influence of taxation on small enterprise development in Russia, Procedia - Social and Behavioral Sciences 166, 216 221 (2015)

5. L. R. Barashyan, International Review of Management and Marketing, 6(S6), 235-240 (2016)

6. Tax Code of the Russian Federation (part two) from 05.08.2000 N 117-Ф3 (ed. From 29.12.2020) http://www.consultant.ru/document/cons_doc_LAW_28165/ (Last accessed 2021/02/12)

7. N. Zotikov, Improving taxation of agricultural production as a factor of successful development of the agricultural sector in Russia, International AgroScience Conference (AgroScience-2020) Earth and Environmental Science 604, 012018 (2020)

8. E.S. Platonova, fundamentals of taxation and its peculiarities in agriculture. Economics and practical management in russia and abroad, materials of the international scientific and practical conference (2014)

9. A.A. Grudneva, A.S. Babanskaya, Current changes for the unified agricultural taxpayers. Humanitarian, Socio-Economic and Social Science, 5, 201 (2019)

10. I.R. Zaripova, G.M. Zaripova, A.I. Khisaeva, V.N. Akhunova, I.G. Gavrilenko, Single Agricultural Tax as an Instrument of State Support of Agribusiness in the National AgroIndustrial Complex, International science and technology conference "FarEastCon2019", Materials Science and Engineering, 753, 052050 (2020)

11. Sijbren Cnossen. VAT and agriculture: lessons from Europe. Int Tax Public Finance (2018)

12. M. Karim, A. Mansouri, Taxation of Moroccan agriculture: an analysis of the sensitivity of the results of a dynamic computable general equilibrium model. Middle East Development Journal 7(1), 89-107 (2015)

13. N. Malinina, Efficiency evaluation of special regimes of direct taxation in agriculture and the ways of their optimization, Economic Annals-XXI 5-6(2), 41-44 (2013)

14. F. Conto, P. La Sala, P. Papapietro, M. Fiore, Taxation and agriculture: New tools for the competitiveness of agrifood systems. A model of intervention in Basilicata. Economia Agro-Alimentare 14(1), 273-294 (2012)

15. I.P. Chupina, Features of taxation in agriculture of the Russian Federation. Agrarian Herald of the Urals, 10(89) (2011)

16. U. Shakoor, A. Nasir, M. Rashid, N. Khurshid, Z. Husnain, Practical contemplation of nexus between agriculture taxation and agriculture output share: A case of Pakistan, Sarhad Journal of Agriculture 34(3), 526-532 (2018)

17. M. Karim, A. Mansouri, Taxation of Moroccan agriculture: an analysis of the sensitivity of the results of a dynamic computable general equilibrium model, Journal of the Austrian Society of Agricultural Economics 25, 211-220 (2015) 